\title{
A urgência das águas: intervenções urbanas em áreas de mananciais
}

\author{
Water urgency: urban interventions in watershed areas
}

Angélica Tanus Benatti Alvim

Volia Regina Costa Kato

Jeane Rombi de Godoy Rosin

\section{Resumo}

As relações entre políticas urbanas e ambientais representam grandes desafios para a formulação de respostas às pressões urbanas versus a preservação ambiental. Nas áreas de mananciais da Região Metropolitana de São Paulo, os desafios são significativos, sobretudo porque as políticas ambientais e urbanas se confrontam com processos de ocupação espontâneos e precários em áreas protegidas. Este artigo situa o panorama da institucionalização das políticas públicas ambientais e urbanas na área de mananciais da bacia hidrográfica do reservatório Billings, aprofundando o caso do município de São Bernardo do Campo, com destaque para a implementação dos instrumentos urbanísticos que integram habitação e meio ambiente. Os desafios para a recuperação das áreas de mananciais vão além da instituição dos marcos legais. Dependem de estratégias de intervenção inovadoras que envolvem a sociedade civil e que podem sinalizar uma real transformação da realidade das bacias hidrográficas protegidas.

Palavras-chave: mananciais; políticas urbana e ambiental; projeto de recuperação socioambiental; Represa Billings; Região Metropolitana de São Paulo.

\begin{abstract}
The relations between urban and environmental policies represent a great challenge to the formulation of answers to urban pressures versus environmental preservation. In watershed areas of the Metropolitan Region of São Paulo, the dimension of this challenge is particularly significant, mainly because the environmental and urban policies face spontaneous and precarious occupation processes in protected areas. This article sets the panorama of the institutionalization of public policies - urban and environmental - in the watershed area of the Billings reservoir, and investigates the case of the city of São Bernardo do Campo, emphasizing the implementation of urban planning tools that integrate housing and environment. It is possible to conclude that the challenges to the recovery of watershed areas go beyond the imposition of legal landmarks. They primordially depend on innovative intervention strategies that involve the civil society and may signal a real transformation of the reality faced by protected drainage basins.
\end{abstract}

Keywords: watershed area; urban and environmental policies; socio-environmental recovery project; Billings Reservoir; São Paulo's Metropolitan Area. 


\section{Introdução}

Os processos de produção social do espaço urbano das cidades brasileiras, dissociados de políticas públicas e projetos urbanos articulados e includentes, têm potencializado os desastres, as catástrofes, os riscos e as vulnerabilidades no meio urbano. Nesse sentido, a associação entre riscos e vulnerabilidade, quando enfocados na perspectiva da instalação precária de moradias em áreas de proteção ambiental, principalmente sobre as que abrigam os mananciais de abastecimento de água, em que o comprometimento dos recursos hídricos se aliam a situações de risco social, é uma situação recorrente e crítica.

Segundo Mendonça e Leitão (2008), a intensa urbanização produz impactos no meio físico que podem ser observados direta e indiretamente. 0 crescimento desordenado das cidades gera inúmeros problemas com sérias consequências para a sociedade, tais como impermeabilização do solo, alterações na drenagem urbana, enchentes, deslizamentos, desastres provocados pela alteração no escoamento natural das águas pluviais, alteração de clima, entre outros.

0 enfrentamento desses problemas, considerando sua natureza complexa, vem exigindo a convergência das políticas urbanas e ambientais, tanto em termos de instrumentos legais que abram horizontes de integração, quanto no plano das intervenções efetivas onde se inserem agentes institucionais e escalas de governo diversos. Reconhece-se que as relações necessárias das políticas públicas, sobretudo nas interfaces entre cidade e meio ambiente, se inserem num campo de forças complexo e conflituoso na medida em que os desafios dos problemas contemporâneos a serem enfrentados questionam os traços setoriais dessas políticas, engendrados há longo tempo.

Apesar do avançado arcabouço legal que hoje o Brasil tem, em termos de políticas urbana e ambiental, evidencia-se ainda, uma enorme lacuna nas ações de planejamento e gestão de áreas protegidas, considerando tanto seus atributos ambientais, de forma a preservá-los, quanto suas dinâmicas sociais e preexistências urbanas. Assim, planos e projetos urbanos desenvolvem-se, na maioria das vezes, de forma não convergente, desarticulados, ou fundados na instabilidade de acordos políticos de curto e médio prazos.

Em áreas de proteção de mananciais, a dimensão desses desafios é especialmente significativa, pois ocupações urbanas, precárias, vêm ocorrendo de forma crescente e adensada, comprometendo os recursos hídricos necessários ao abastecimento humano, em termos de quantidade e qualidade, numa escala que ultrapassa as demandas locais.

$\mathrm{Na}$ atualidade, a Região Metropolitana de São Paulo - RMSP - se encontra à beira de um colapso urbano e ambiental, decorrente da ausência de chuvas e, consequentemente, da drástica redução de água para abastecimento. Trata-se da maior seca em 84 anos, em uma região que hoje abriga a maior população do Brasil, aproximadamente 20 milhões de habitantes.

Para o poder público estadual, a responsabilidade dos preocupantes índices que hoje assolam a falta de água em São Paulo, particularmente nas represas que compõem o Sistema Cantareira (responsável por $45 \%$ do fornecimento de água para aproximadamente 
9 milhões de habitantes da RMSP), é o "clima", com destaque para a falta de chuvas. Toledo Silva (2014) enfatiza que o processo histórico de crescimento descontrolado dos núcleos urbanos, ao longo dos anos degradou o ambiente, contribuindo para o atual cenário crítico. Para o autor, o desmatamento, a impermeabilização do solo, a ocupação de zonas ribeirinhas, entre outros, criou ilhas de calor e afetou em muito a precipitação de chuvas. Parte de um "círculo vicioso", são acrescidos outros fatores importantes que contribuem para agravar tal situação: perdas físicas no sistema de abastecimento de água, ausência de tratamento integrado de esgotos, assoreamento dos cursos d'água, não reflorestamento de cabeceiras, e principalmente ausência de políticas públicas integradas.

Nesse contexto, evidencia-se que o desenvolvimento urbano tem forte interface com a gestão dos recursos hídricos, particularmente com a gestão das águas urbanas - que incluem abastecimento de água e saneamento, setores que por sua natureza histórica e político-institucional não foram tratados de forma integradas.

Se por um lado a gestão dos recursos hídricos no Brasil é realizada por bacias hidrográficas, e o domínio é federal ou estadual, por outro, a gestão urbana é responsabilidade do município.

Nas áreas de proteção dos mananciais da metrópole de São Paulo, as políticas públicas voltadas para a preservação, conservação e recuperação das bacias hidrográficas que abrigam os principais reservatórios hídricos da metrópole, têm sido pouco efetivas. Fundadas na instabilidade de acordos de médio e longo prazos, deparam-se com conflitos históricos político-institucionais e de gestão, envolvendo legislações, regulamentos e ingerências de instâncias diferenciadas em várias esferas do Poder Público - federal, estadual e municipal.

A instituição da legislação de proteção e recuperação dos mananciais em 1997 (Lei Estadual n. 9.866) tem como desafio implementar possibilidades de regulação e de intervenção nas bacias protegidas da RMSP, reconhecendo, ao mesmo tempo, os atributos ambientais e as preexistências de ocupação urbana, num processo paulatino e crescente de avanço sobre as áreas de mananciais. A publicação das leis específicas no âmbito das bacias hidrográficas das represas Guarapiranga e Billings em 2006 e 2009, respectivamente, fez emergir um novo quadro normativo que visa a regulamentação do uso e ocupação do solo nessas áreas e a definição de instrumentos de recuperação e de regularização da ocupação irregular, com vistas a melhorar sua condição ambiental e com isso ampliar a disponibilidade do recurso água para o abastecimento público. Parte de um processo de médio e longo prazos, as diretrizes e normas contidas nessas legislações têm forte interdependência com as políticas urbanas relacionadas a legislação de usos e ocupação do solo, regularização fundiária, projetos urbanos e políticas de provisão habitacional, entre outras que deveriam ser implementadas de forma integrada com as legislações de proteção das áreas de mananciais, contribuindo a médio e longo prazo para minimizar os conflitos que incidem sobre a disponibilidade da água.

Fruto de pesquisa em andamento, ${ }^{1}$ este artigo busca apresentar as interfaces e os conflitos entre os instrumentos ambientais e urbanos que incidem sobre as áreas de mananciais, tendo como estudo de caso o município de São Bernardo do Campo, situado na 
bacia hidrográfica do reservatório Billings. As análises realizadas permitem identificar um avanço importante no processo de formulação da política urbana de São Bernardo do Campo articulados à implementação de projetos de recuperação de habitação de interesse social na bacia hidrográfica Billings. Ao mesmo tempo, expõe os conflitos entre os instrumentos urbanos, representados pelo Plano Diretor, e os ambientais, representado pela legislação de proteção e recuperação dos mananciais.

Apesar de a nova política de mananciais incorporar instrumentos urbanísticos visando a recuperação das áreas degradadas e manutenção da habitação em áreas preservadas, 0 caso de São Bernardo do Campo ilustra que os desafios vão além da instituição dos marcos legais. Dependem fundamentalmente de um processo de negociação entre os organismos estaduais e os municípios, envolvendo um diálogo permanente e, sobretudo da implementação de Programas de Recuperação de interesse Social (PRIS) em áreas precárias com projetos que aliam as agendas ambiental e urbana de forma integrada e inovadora, sinalizando uma real transformação da realidade das bacias hidrográficas protegidas.

\section{Bacia hidrográfica como unidade de planejamento e gestão}

O debate sobre a escassez da água não é recente. Insere-se no amplo debate sobre recursos naturais renováveis e não renováveis. Para Fracalanza (2002), a escassez da água, na atualidade, deve ser considerada sob dois prismas distintos, porém interligados: o primeiro diz respeito à quantidade de água necessária à execução das atividades humanas no território, e o segundo relaciona-se à qualidade da água a ser utilizada nessas atividades. Além de levar em conta esses dois prismas, o potencial de renovabilidade desse recurso, num dado território, deve ser também considerado como um importante definidor de sua escassez ou abundância.

Em diversos trabalhos (Alvim, 2003; 2010), enfatizamos que a futura escassez da água impõe a busca de novos modelos de planejamento e gestão que visam conciliar os recursos hídricos, o território e a sociedade no âmbito da bacia hidrográfica.

As virtudes e os defeitos dos cursos d'água, de acordo com Saraiva (1999), são, nada mais, que os reflexos das ações antrópicas diretas ou indiretas sobre a bacia hidrográfica, sua área de influência se estendendo por onde permeia seu escoamento. Sob o ponto de vista do ciclo hidrológico, a lógica territorial da bacia hidrográfica é determinante, tendo em conta a capacidade de renovação e manutenção desse recurso em quantidade e qualidade que permitam sua utilização pelos seres vivos, sendo muitas vezes subordinada aos processos de planejamento e gestão que privilegiam outras lógicas setoriais.

Em Alvim (2003), afirmamos que o planejamento e a gestão integrada dos recursos hídricos são essenciais para o desenvolvimento da sociedade humana e fator de manutenção dos ecossistemas. Esse modelo deve levar em conta as interações com os sistemas naturais e socioeconômicos, no âmbito das bacias hidrográficas, significando que a gestão de todo o território que integra determinada bacia deve 
ser integrada de forma a minimizar os conflitos em torno deste recurso.

Dourojeanny (1993) afirma que a gestão integrada da bacia hidrográfica visa conciliar políticas setoriais de gestão do território e políticas setoriais de gerenciamento dos recursos hídricos no âmbito da bacia, além de integrar equitativamente os usuários (instituições, empresários e sociedade civil) em relação ao planejamento e aproveitamento dos recursos hídricos e dos demais recursos. Para o autor, 0 modelo de gestão integrada da bacia hidrográfica prioriza o potencial hídrico e as necessidades de manejo dos recursos naturais em uma forma ambientalmente sustentável, sendo a água considerada o principal eixo de articulação para coordenar as ações de crescimento econômico e equidade.

No entanto, a adoção da bacia hidrográfica como unidade de planejamento e gestão deve considerar sua relação com outros sistemas e instituições que funcionam com limites distintos, sobretudo os limites político-administrativos, pois esses são bases das políticas territoriais, principalmente as que incidem no meio urbano.

No Brasil, a Constituição Federal de 1998 reforçou lógicas distintas e muitas vezes conflitantes, das políticas territoriais e ambientais. Enquanto as políticas urbanas e regionais orientam-se pelos critérios político-administrativos num dado território, as políticas de meio ambiente e dos recursos hídricos estão sujeitas, predominantemente, aos aspectos ambientais que não se restringem aos limites políticos-administrativos. A descentralização político-administrativa propiciada pela Constituição Federal ampliou a competência dos municípios, dando-Ihes maior autonomia política, fiscal e financeira, reconhecendo a posição estratégica das cidades e principalmente no que se refere ao meio urbano. Em seu artigo 182, a Constituição Federal delega ao município a responsabilidade da política urbana, definindo o Plano Diretor municipal como o principal instrumento de desenvolvimento urbano; no artigo 25, define que o Estado é responsável pela organização regional, atribuindo-Ihe a competência de definir áreas metropolitana, aglomeração urbana e microrregião e, consequentemente as políticas de caráter intermunicipal. Já em seus artigos 21 e 225, detalha as especificidades das políticas hídricas e ambientais, respectivamente, ressaltando que ambas são competências comuns dos três níveis de governo. Desse modo sempre que houver a necessidade de planejamento e gestão de rios, bacias hidrográficas ou outras unidades ambientais que extrapole os limites político-administrativos de um município, há que considerar o nível de governo hierarquicamente superior.

Martins (2006) aponta que, enquanto os municípios, ou mesmo os Estados, muitas vezes são limitados pelo eixo de um rio, todas as atividades que se referem à água - como o abastecimento, esgotamento sanitário, drenagem, etc. - exigem outro tipo de critério de organização espacial, em geral, as bacias ou microbacias hidrográficas, podendo vir a extrapolar limites político-administrativos municipais ou mesmo, estaduais. Essas atividades, consideradas essenciais ao desenvolvimento urbano de um determinado município, ao obedecer a uma lógica setorial e espacial distinta, exigem atuação de outros níveis político-administrativos. Tais padrões tendem a se contrapor, uma vez que essas políticas estão em instâncias distintas de governo e, muitas vezes, encontram-se 
em campos de conflitos interinstitucionais, e ao mesmo tempo, o cumprimento dos dispositivos constitucionais depende de uma ação conjunta, negociada entre os poderes públicos federal, estadual e municipal.

Toledo Silva (2002, p. 464) afirma que o modelo de gestão das bacias hidrográficas, ainda que com ênfase nos recursos hídricos, aliado a possibilidade de articulação às instâncias instituídas pela Constituição Federal - regiões metropolitanas, aglomerações urbanas e microrregiões - pode vir a configurar um caminho alternativo à organização regional, com uma trajetória diferente das regionalizações anteriores. Para o autor, a gestão integrada das bacias hidrográficas evoca a articulação inter-setorial, institucional e partilhada desses territórios. Assim, esse modelo difere do planejamento setorial e visa, sobretudo a uma "visão-horizontal, inter-setorial e multidisciplinar". Como parte dos principais desafios, devem ser propostos modelos integrados de planejamento e gestão que considerem, dentre os componentes ambientais na tomada de decisão nos vários níveis de intervenção (Estado e municípios), a participação da comunidade envolvida.

\section{Políticas ambientais e urbanas nos mananciais - sul da RMSP: marcos legais e conflitos políticos institucionais}

A Política Estadual de Recursos Hídricos de São Paulo - Lei n. 7.663/1991 - e a Lei Estadual de Proteção dos Mananciais - Lei n. 9.866/1997 - incidem sobre os recursos hídricos e sobre as áreas que protegem os mananciais estaduais de abastecimento de água, incorporando a bacia hidrográfica como unidade de planejamento, gestão e intervenção.

A instituição da Política Estadual de Recursos Hídricos de São Paulo - Lei n. 7.663/1991 - foi pioneira no Brasil, ao adotar a bacia hidrográfica como unidade de planejamento e definir Comitês de Bacia como organismos responsáveis pela gestão descentralizada e participativa dos recursos hídricos. Essa lei, além de inspirar a Política Nacional de Recursos Hídricos instituída pela Lei 9.433/1991, orientou a revisão, em 1997, da Legislação de Proteção dos Mananciais do Estado de São Paulo (LPM), instituída em meados da década de 1970 e considerada ultrapassada e ineficaz. $^{2}$

A aprovação da lei estadual de Proteção e Recuperação dos Mananciais (Lei Estadual n. 9.866/1997) abriu uma nova perspectiva de recuperação ambiental das áreas de mananciais, da metrópole, em seus trechos degradados, envolvendo todos os atores em busca de uma gestão integrada principalmente entre Estado, municípios e sociedade civil organizada. De acordo com ela, no âmbito de cada bacia ou sub-bacia hidrográfica do Estado de São Paulo que têm Área de Proteção e Recuperação dos Mananciais (APRM), devem ser definidas e detalhadas leis específicas que estabelecem diretrizes e instrumentos levando em conta as seguintes áreas de intervenção: 1) Área de Restrição à Ocupação (ARO) - aquelas de especial interesse para a preservação, conservação e recuperação dos recursos naturais da bacia devendo ser prioritariamente destinadas à produção de água, mediante a realização de investimentos e a aplicação dos instrumentos 
econômicos e de compensação previstos; 2) Área de Ocupação Dirigida (AOD) - aquelas que buscam uma sustentabilidade entre questões sociais, econômicas e ambientais por meio da consolidação ou implantação de usos urbanos ou rurais, que atendam certos requisitos necessários a manter a qualidade e a quantidade de produção de água; 3) Área de Recuperação Ambiental (ARA), são ocorrências localizadas de usos ou ocupações que estejam comprometendo a quantidade e a qualidade das águas, exigindo intervenções urgentes de caráter corretivo e que podem ser consideradas transitórias.

Cada APRM deve ser dotada de um sistema de gestão próprio, segundo os princípios de gerenciamento participativo e descentralizado da Política Estadual de Recursos Hídricos - Lei 7.633/1991, vinculado ao Comitê de Bacia. Esse sistema é composto de três instâncias - órgão colegiado; órgão técnico e órgãos da administração pública - que buscam garantir participação, estrutura de apoio ao desenvolvimento de trabalhos técnicos e envolvimento dos órgãos setoriais do Estado e instâncias municipais.

\section{A Bacia Hidrográfica do Alto Tietê e a Lei de Proteção e Recuperação dos Mananciais}

A Bacia Hidrográfica do Alto Tietê, região que abriga 34 dos municípios da RMSP e cerca de $90 \%$ de sua população total, é uma bacia localizada na cabeceira de seu maior rio, o Tietê, cuja vazão média é de apenas $90 \mathrm{~m}^{3} / \mathrm{segun}$ do. Desde sua nascente até a Barragem de Pirapora (Pirapora do Bom Jesus), suas águas apresentam um quadro crítico de poluição. Sua disponibilidade hídrica, em condições normais, é de apenas 200 metros $^{3} /$ habitante ao ano, índice considerado muito abaixo do recomendado pela ONU. ${ }^{3}$

Nas três últimas décadas do século $\mathrm{XX}$, a expansão da metrópole de São Paulo dirigiu-se prioritariamente para as regiões leste e sul, e na última década intensificou-se para o norte. A região sul está inserida na área de proteção dos mananciais das sub-bacias Guarapiranga e Billings e ao norte a sub-bacia Juqueri-Cantareira, ${ }^{4}$ onde se localiza o sistema Cantareira, principal manancial de abastecimento de água.

De um modo geral, tal expansão urbana é horizontal e descontínua, com altas taxas de desmatamento, poluição e degradação de recursos hídricos. Trata-se de um padrão predatório que associa a falta de sincronia entre a escala da urbanização precária local e a ausência de instalação de sistemas de infraestrutura de saneamento ambiental na escala regional. Dados do último Censo Demográfico do IBGE de 2010 apontam que a população total dos principais mananciais da RMSP se distribuía da seguinte maneira: 1) sub-bacia Guarapiranga - 863 mil habitantes, sendo responsável pelo abastecimento de 3,5 milhões de habitantes da RMSP (cerca de $20 \%$ da sua população); 2) sub-bacia Billings - 895 mil pessoas, sendo o braço Rio Grande do reservatório o responsável pelo abastecimento de cerca de 1,6 milhões de habitantes ; 3) sub-bacia Juqueri-Cantareira - 79.105 mil pessoas, que apesar de sua população ser muito inferior às demais sub-bacias, o subsistema Cantareira é responsável pelo abastecimento de aproximadamente 8,1 milhões de pessoas da RMSP. 
Associados ou não aos processos de expansão urbana, os processos de desmatamento ocorridos nas Áreas de Proteção aos Mananciais da RMSP nos últimos anos significativos como apontam Oliveira e Alves (2006). Os autores indicam que as APMs ocupam 40,3\% do território da metrópole e respondem por $63,8 \%$ da sua cobertura florestal, $(60,4$ mil hectares). Entre 1991 e 2000, década em que realizaram extensa pesquisa, houve perda de cobertura florestal de 8,6 mil hectares, representando uma expressiva taxa de desmatamento de $12,4 \%$ (ou $5,9 \%$ em relação ao seu território). De um total de 13,4 mil hectares desmatados na RMSP entre 1991 e 2000, 70,2\% ocorreram no interior de áreas ambientalmente protegidas, sendo 64\% no interior das APMs.

A partir de 1994, com a instituição do fórum de gestão da água, o Comitê da Bacia Hidrográfica do Alto Tietê, e de suas instâncias descentralizadas - os cinco subcomitês de bacia (Cotia-Guarapiranga; Billings-Tamanduateí; Tietê-Cabeceiras; Juqueri-Cantareira e Pinheiros-Pirapora) - possibilitou aproximar a atuação dos principais organismos setoriais do Estado à dos municípios que estão em área de proteção dos mananciais na busca de uma solução conjunta para seus principais problemas. Principalmente a partir de 1997, com a aprovação da "nova Lei de Proteção e Recuperação dos Mananciais", novos instrumentos de planejamento e gestão começaram a ser construídos para equacionar os problemas relativos não somente à degradação dos mananciais, mas também à melhoria da qualidade de vida de seus habitantes (Alvim, Kato e Bruna, 2008).

Até 2013, apenas as duas sub-bacias Guarapiranga e Billings - que integram a Bacia do Alto Tietê, têm leis específicas. A sub- -bacia Guarapiranga, ou Área de Proteção e Recuperação dos Mananciais Guarapiranga - APRM-G, foi pioneira com a aprovação da Lei Estadual n. 12.233 /2006; regulamentada pelo Decreto n. 51.686 de 2007; seguida pela sub-bacia Billings, ou APRM-B, cuja Lei Estadual n. 13.579 foi aprovada em 2009 e regulamentada pelo Decreto Estadual $n$. 55.342/ 2010. 0 processo de elaboração da lei específica da APRM - Alto Juqueri-Cantareira deflagrado pelo subcomitê Juqueri- Cantareira em 2009 foi encaminhado pelo Executivo Estadual como Projeto de Lei 272 a Assembleia Estadual, até o final da pesquisa encontrava-se em discussão.

Nessas sub-bacias, as novas legislações procuram, de maneiras distintas, equacionar os problemas relativos à degradação dos mananciais e às ocupações irregulares. As duas legislações definem áreas de intervenção conforme as características de uso e ocupação do solo das sub-bacias, buscando orientar os planos diretores municipais que devem ser compatíveis com os parâmetros urbanísticos por elas definidos. Em ambas as legislações preveem-se formas de licenciamento do uso e ocupação do solo e de regularização em casos que estejam em desconformidade com os parâmetros urbanísticos e normas estabelecidos pelas respectivas leis, ou mesmo pelas legislações municipais, desde que sejam implementadas medidas de compensação de natureza urbanística, sanitária ou ambiental (Alvim, 2010).

0 mapa de Áreas de Intervenção definido em cada sub-bacia é o instrumento norteador para a aprovação de novos empreendimentos, bem como para a regularização de moradias no âmbito municipal. Tais áreas devem ser utilizadas pelos municípios como 
uma base para revisão de seus Planos Diretores a fim de tornar seu ordenamento territorial compatível com os parâmetros definidos nas leis específicas. A Figura 1 apresenta as áreas protegidas da RMSP ( $53 \%$ do território metropolitano) e da Bacia do Alto Tietê, destacando as duas sub-bacias que possuíam até a finalização da pesquisa suas legislações específicas de proteção e recuperação dos mananciais.

A Figura 2 apresenta, de forma conjunta, a espacialização das áreas de intervenção previstas nas leis específicas das duas APRMs.

Figura 1 - RMSP: áreas legalmente protegidas

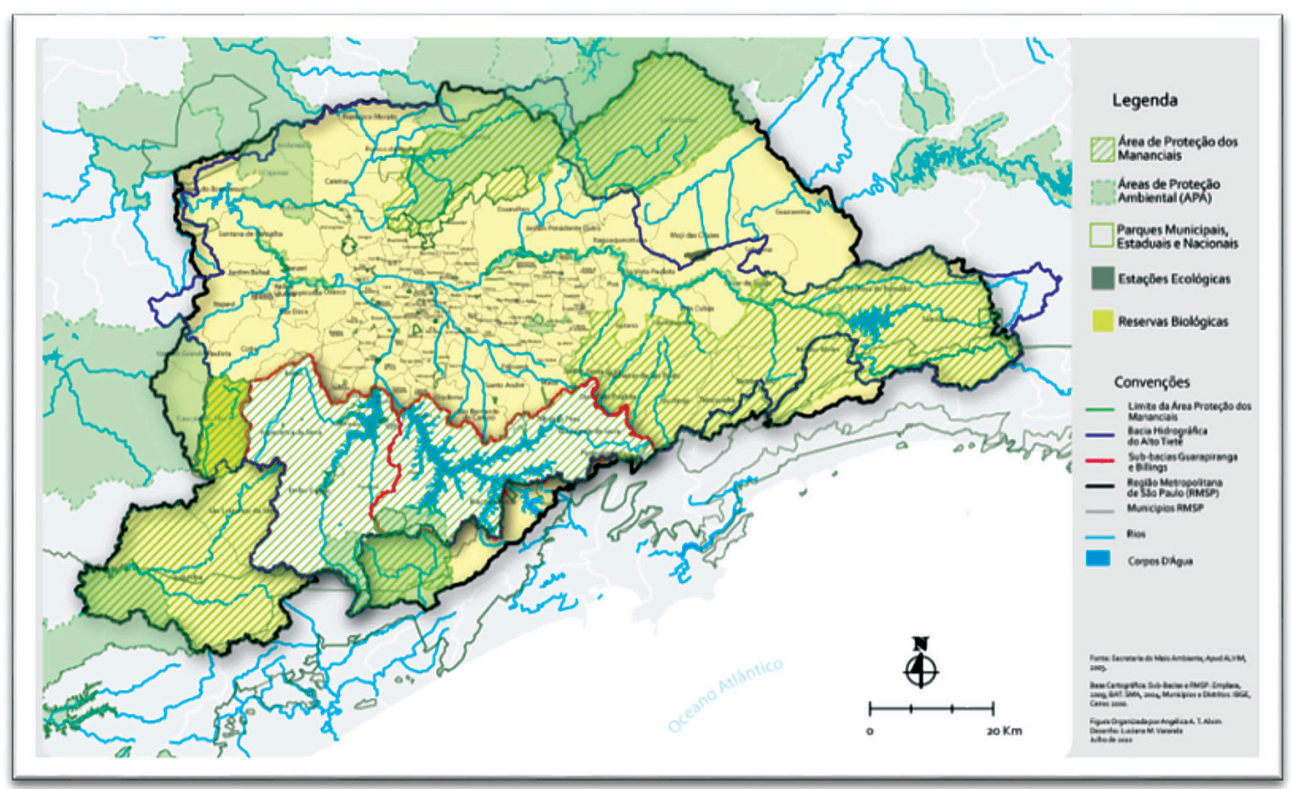

Fonte: Alvim (2010). Mapa elaborado a partir de dados obtidos na Emplasa. 
Figura 2 - Espacialização das áreas de intervenção de duas APRM

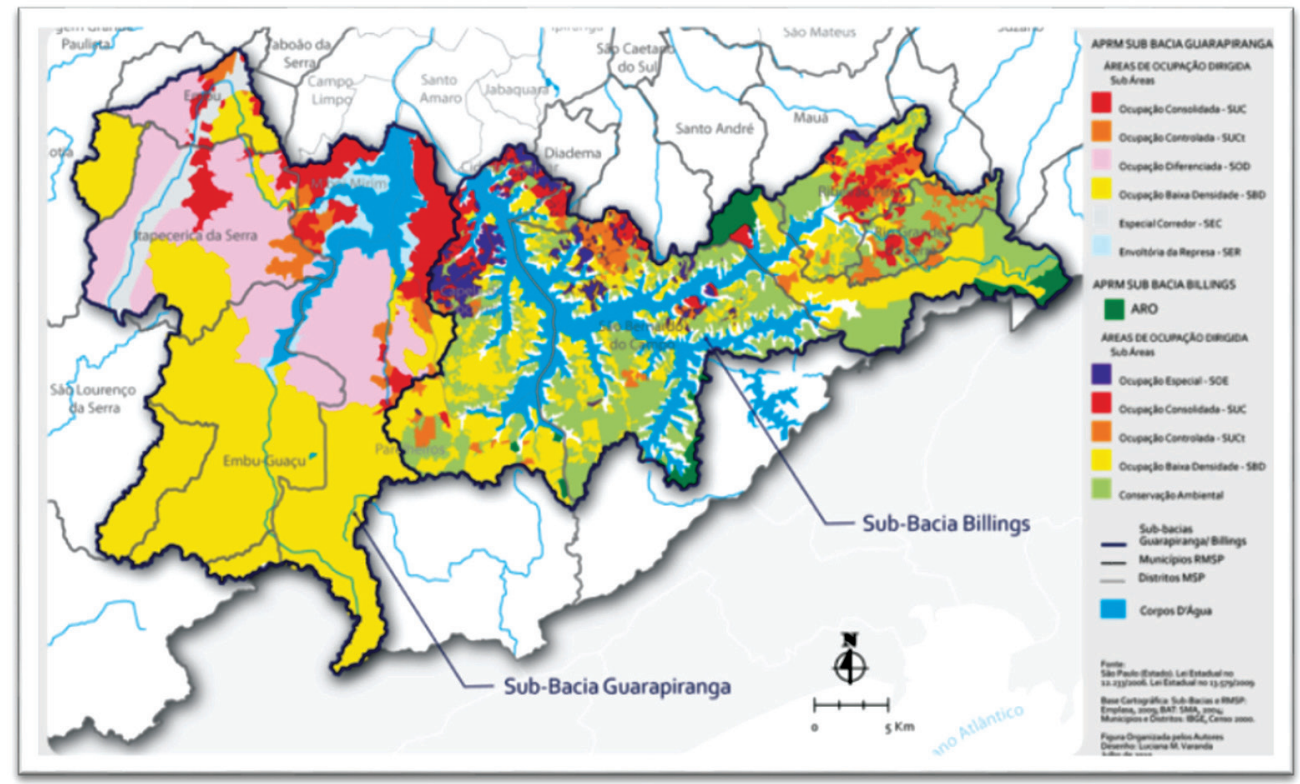

Fonte: Alvim (2010). Mapa elaborado a partir das bases da Leis Específicas das APRM-Guarapiranga.

De forma diferenciada, essas legislações procuram apontar possibilidades de projetos de intervenção em áreas precárias, considerando essas uma importante realidade a ser equacionada e, ao mesmo tempo, orientar os planos diretores municipais a redefinirem seus instrumentos em consonância com as diretrizes ambientais. 0 Programa de Recuperação de Interesse Social - PRIS é um instrumento ambiental e simultaneamente urbanístico fundamental a ser utilizado em áreas degradadas, particularmente em ARA 1, conforme determina a lei específica.

Do ponto de vista das políticas urbanas, observa-se que os municípios da sub-bacia Guarapiranga desencadearam um processo de busca de adequação e integração dos Planos Diretores e das leis de uso e ocupação do solo com a legislação ambiental específica em vigor. Entre 2006 e 2012, todos os municípios revisaram seus planos diretores municipais tendo como meta essa compatibilização. Em artigo anterior (Alvim, Kato, Bruna, 2012), apontamos os inúmeros conflitos que ainda persistem, os quais incidiram, inclusive, na necessidade de revisão da lei específica dessa sub-bacia.

Na mesma direção, a lei específica da APRM-Billings deflagrou, desde 2010, o processo de revisão dos planos diretores dos municípios localizados naquele sub-bacia. Entre 2011 e 2013, os municípios de Santo André, São Bernardo do Campo e Ribeirão Pires revisaram 
seus planos diretores, aprovando-os como leis municipais. Nesse contexto, o município de São Bernardo implementou um processo de revisão participativo amparado por um estudo que já pontuava os conflitos entre a lei ambiental e a realidade do território. A promulgação em 2011 do novo Plano Diretor de São Bernardo do Campo, apesar de buscar a compatibilização com a lei específica, sinaliza a importância de que esse processo não deve ser visto como algo unilateral em que apenas a política urbana deve adequar-se à ambiental e, sim, destaca a necessidade de revisão do próprio instrumento ambiental em articulação às propostas do plano diretor, no âmbito de um diálogo permanente de gestão das áreas de mananciais. $A$ síntese da política habitacional ilustra a implementação do instrumento PRIS - Programa de Recuperação de Interesse Social, definido na lei específica de mananciais, envolvendo projetos inovadores nessa municipalidade que buscam articular a moradia e a preservação ambiental.

\section{São Bernardo do Campo: política urbana e legislação dos mananciais}

0 município de São Bernardo do Campo, localizado na sub-região sudeste da RMSP, pertence à microrregião do $A B C D$ formada por Santo $A n-$ dré, São Bernardo do Campo, São Caetano do Sul, Diadema, Mauá, Ribeirão Pires e Rio Grande da Serra. A localização geográfica de São Bernardo do Campo é estratégica: localiza-se entre a capital, principal ponto de aglomeração do estado de São Paulo, e o Porto de Santos, importante área de exportação do país; único município interceptado pelas rodovias Anchieta e Imigrantes; no sentido leste-oeste é cortado pelo Rodoanel Mario Covas, via expressa, de ligação metropolitana.

Com uma área total de $407,1 \mathrm{~km}^{2}$, no alto da Serra do Mar, do planalto Atlântico, São Bernardo do Campo $^{5}$ tem $52 \%$ de seu território classificado como Área de Proteção dos Mananciais Billings (APRM-B), e 18,6\% de sua área total é ocupada pela represa Billings (PMSBC, 2006). 0 avanço histórico da ocupação urbana sobre áreas de mananciais da sub-bacia Billings se expressa em São Bernardo do Campo de maneira expressiva, acompanhando as tendências da urbanização espraiada da metrópole, sobretudo a partir da década de 1970.

Em São Bernardo do Campo, os conflitos entre urbanização e meio ambiente são especialmente muito expressivos, confrontando o crescimento demográfico com as contenções institucionais de crescimento da mancha urbana, uma vez que metade do território do município se insere nas reservas de proteção dos mananciais e da Serra do Mar.

\section{0 novo Plano Diretor Municipal de São Bernardo do Campo de 2011}

0 interesse na compatibilização da legislação municipal sempre se fez presente no âmbito dos processos de gestão municipal de São Bernardo do Campo, com destaque para o momento de elaboração da lei específica quando o município teve importante participação no 
subcomitê Billings-Tamanduateí. 0 Plano Diretor de 2006, ${ }^{6}$ ainda que anterior à Lei Específica da APRM-B, já considerou em suas diretrizes os conceitos de preservação, conservação e recuperação das áreas de mananciais e definindo instrumentos adequados às características de cada região.

Durante o ano de 2010, o Plano Diretor de SBC de 2006 foi revisto buscando garantir a função social da cidade e compatibilizar suas diretrizes e parâmetros às normas ambientais e índices urbanísticos de interesse para a preservação, conservação e recuperação dos mananciais da Lei Estadual n. 13.579/2009, ciente que essa revisão e sua posterior aprovação condicionariam a municipalização das atividades de licenciamento e de regularização.

No recorte temporal definido pela pesquisa, a compatibilização do Plano Diretor encontrava-se em processo de aprovação junto à Secretaria Estadual do Meio Ambiente e ao Comitê da Bacia Hidrográfica do Alto Tietê. Enquanto não for concluída a referida adequação, os terrenos localizados na APRM - Billings deverão atender aos requisitos da legislação estadual no que se refere à ocupação do solo, bem como submeter-se ao licenciamento ambiental estadual (PMSBC, 2011)

O novo Plano Diretor do Município de São Bernardo do Campo, instituído pela Lei $\mathrm{n}^{\circ} 6.184$ em 21 de dezembro de 2011, foi fruto de um amplo processo de discussão pública ao longo de um ano de trabalho, envolvendo os diferentes segmentos sociais da população, suas organizações e a instância colegiada do Conselho da Cidade e do Meio Ambiente do município.
0 Plano Diretor de 2006, aprovado anteriormente a Lei Específica, apesar de inovador, apresentava diversas incompatibilidades com a Lei da APRM-Billings, seja pelos índices inadequados reafirmados pela Lei de Uso e Ocupação do Solo de 2007, seja pela inobservância dos aspectos da realidade de ocupação do território municipal contida na legislação ambiental.

Reafirma-se, no Plano Diretor de 2011, a incorporação de diretrizes ambientais na política urbana ao lado das considerações sociais mais amplas de qualidade de vida, delimitada em seus princípios fundamentais (Capítulo II, Art. 4) nos quais se enfatizam o desenvolvimento sustentável e a função social da cidade. Especificamente no artigo 8, o PDSBC dispõe sobre os objetivos gerais da política urbano-ambiental que trata da prioridade da preservação das áreas ambientalmente sensíveis, especialmente a APRM-B, da ordenação e controle do uso e ocupação do solo urbano, sem que haja incompatibilidades de usos e efeitos negativos sobre o meio ambiente; da utilização dos instrumentos urbanísticos para garantir a função social da propriedade, a busca pela diminuição da desigualdade social garantindo o acesso à rede de infraestrutura, mobilidade, e o direito à moradia digna, elevando a qualidade de vida da população. Esse artigo também trata de uma questão bastante pertinente que é a emergência de articulação entre a esfera local às demais esferas de governo, com vista de um desenvolvimento integrado.

Observa-se a intenção expressa de compatibilização entre políticas urbanas e ambientais acatando as ações socioeconômicas na sub-bacia Billings, no sentido de preservar 
e recuperar as áreas de mananciais, mencionando a importância do controle e fiscalização sobre agentes impactantes além da importância do fomento ao uso sustentáveis das águas no município.

Ainda do ponto de vista da integração e compatibilização de políticas no plano municipal, destacam-se os pressupostos sociais presentes no Estatuto da Cidade (2001) referendando nas diretrizes da Política Habitacional, a importância da universalização dos direitos à moradia digna, a promoção da urbanização e regularização fundiária em áreas precárias propiciando sua inserção urbana de forma sustentável. Especificamente, o artigo 18 apresenta 0 PLHIS (Plano Local de Habitação de Interesse Social) como instrumento de implementação da Política Habitacional no Município. Através desse instrumento, pretende-se gerar um diagnóstico da situação/precariedade dos assentamentos, auxiliando, dessa forma, o poder público a caracterizá-los e priorizar as estratégias de intervenção. 0 artigo 19 trata do Plano Municipal de Saneamento Básico que deverá estar em conformidade com a Política Nacional de Saneamento Básico instituída pela Lei Federal n. $11.445 / 2007$.

0 ordenamento territorial estabelecido pelo Plano Diretor de 2011, constitui, de acordo com os posicionamentos desta pesquisa, o aspecto central da compatibilização entre regulações urbanas e ambientais em escalas múltiplas, pois não apenas direciona as formas de ocupação como instrui possibilidades de reversão de processos ambientalmente problemáticos relacionados ao crescimento demográfico e ao desenvolvimento econômico do município.

\section{Compatibilização do PDSBC à lei específica e os conflitos indicados}

Em estudo realizado pela PMSBC entre os anos de 2010 e 2011, intitulado "Compatibilização do Plano Diretor do município de São Bernardo do Campo à Lei Estadual n. 13.579, de 13 de julho de 2009" (PMSBC, 2012a), os parâmetros estabelecidos pela Lei específica, bem como a delimitação das áreas e subáreas, foram objeto de análise pormenorizada, dando subsídios ao novo Plano Diretor bem como apontando problemas relacionados à lei específica.

0 resultado dessa análise foi a observação de diversos conflitos por compartimento ambiental da Billings entre o que preconiza a lei ambiental e a realidade de ocupação da região. Os conflitos identificados ora apontam problemas relacionados à pouca restrição da lei específica, pois incidem em áreas ainda preservadas, ora apontam para problemas relacionados à desconsideração de loteamentos e favelas existentes.

O novo Plano Diretor de SBC, tendo por base esse documento, procurou se adequar à realidade de ocupação da sub-bacia, assumindo que os conflitos delineados no âmbito da lei específica deveriam ser alvo de um processo de negociação entre Estado e município, indicando inclusive a revisão da lei ambiental.

A pesquisa que dá origem a este artigo procurou aprofundar a discussão, analisando os instrumentos definidos pelo PDSBC em comparação com os indicados pela Lei Específica. A análise comparativa selecionou nas duas legislações os índices urbanísticos relativos ao 
Lote mínimo, Coeficiente de Aproveitamento (CA), Taxa de permeabilidade e Índice de área vegetada. Esses índices são considerados básicos para a determinação do grau de compatibilidade entre as leis e a sinalização de uma nova postura institucional de criação de instrumentos comuns que possam subsidiar ações compartilhadas (Alvim et al., 2014).

0 Zoneamento proposto pelo Plano Diretor considera as áreas de forma homogênea, enquanto a Lei Específica propõe uma subdivisão do território em porções menores levando em consideração os compartimentos ambientais definidos a partir da geomorfologia do reservatório Billings. Ou seja, uma área apontada no PDSBC corresponde a várias áreas na Lei específica da APRM-B, constatando-se que os critérios de diferenciação geomorfológica das áreas de proximidade dos corpos d'água são priorizados na legislação estadual. Tal fato vai incidir no conflito entre realidade de ocupação e parâmetros definidos pela lei específica, como será destacado a seguir.

O lote mínimo já configurava-se, desde 2006, como o principal ponto de conflito entre a Lei específica e o PDSBC, e em 2011, é um dos aspectos polêmicos entre ambas as legislações. Verifica-se que o Plano Diretor adotou, em algumas porções do território, índices mais restritivos do que os definidos pela Lei Específica como lote mínimo principalmente nas áreas mais ao sul da sub-bacia onde identificam-se áreas ainda preservadas. Em outros trechos ao norte, principalmente ao longo do Rodoanel Mario Covas, o lote mínimo é menos restritivo.

Em relação ao Coeficiente de Aproveitamento (CA), o estudo realizado pela PMSBC (2012) levantou as dimensões (m2) das áreas e subáreas de intervenção em cada um dos compartimentos ambientais definidos pela lei específica e pelo proposto no PDSBC. Esse valor em $\mathrm{m} 2$ foi multiplicado pelo CA, constante na lei específica e na proposta municipal, e resultou na metragem referente ao quanto pode ser construído em cada um dos compartimentos pela lei específica e pela proposta municipal. Considerou-se também que a lei específica não mapeou as áreas de recuperação ambiental, bem como as áreas vazias destinadas a projetos habitacionais. 0 estudo identificou ainda que o Rodoanel e as principais rodovias localizam-se no Corpo Central 1, onde está a área de ocupação urbana mais antiga e consolidada dos mananciais de SBC e sugeriu uma alteração do limite de APRM-B aliada a uma estratégia de aumentar a área ocupada ao máximo da capacidade de suporte e articular o potencial dessa via ao desenvolvimento econômico municipal.

Todo estudo realizado pela PMSBC indica, por um lado, a supressão de áreas verdes e de baixa densidade de alguns trechos, mas, por outro, promove a compensação com a criação de outras áreas de preservação no mesmo compartimento com acréscimos em $\mathrm{m}^{2}$ de áreas verdes. Ou seja, o zoneamento proposto ultrapassa em todos os compartimentos a proporção de áreas permeáveis e vegetadas nos compartimentos, mesmo considerando a existência de ARA 1 em alguns compartimentos que não foram previstos na lei específica.

Por fim, os procedimentos visando a recuperação ambiental foram analisados de forma integrada e intersetorial entre as equipes de planejamento urbano e habitação. Para tanto, foram identificadas as ARA tipo 1 e 2, conforme determina a lei específica, ambas caracterizadas pela ocorrência de usos e ocupações 
que comprometem a quantidade e a qualidade da água, exigindo intervenções de caráter corretivo, da seguinte forma: a) Área de Recuperação Ambiental-1 (ARA-1), formada por assentamentos precários desprovidos, total ou parcialmente, de infraestrutura e saneamento básico, sendo objeto de Programa de Recuperação de Interesse Social - PRIS, que atenderá todas as famílias dos assentamentos habitacionais precários e irregulares identificados no Plano Local de Habitação de Interesse Social; b) Área de Recuperação Ambiental-2 (ARA-2), ocorrências de degradação ambiental que exigem recuperação imediata do dano ambiental, por meio de Projeto de Recuperação Ambiental - PRAM.

Como a lei específica permite a regularização de lotes de $125 \mathrm{~m} 2$ nas Sub-área de Ocupacão Espacial (SOE) e Sub-área de Ocupação Consolidada (SUC) (em todos os compartimentos) e na Sub-área de Ocupação Controlada (SUCt), nos compartimentos Corpo Central 1, Corpo Central 2 e Itaquaquecetuba-Bororé (em casos de ocupação existente até a data de aprovação da Lei), a Secretaria Municipal de Habitação de SBC elaborou um mapeamento detalhado dos assentamentos precários do município, favelas e loteamentos irregulares, identificando onde seriam os focos de regularização que foram grafadas como ARAS 1 e implementação do PRIS - Programa de Recuperação de interesse Social.

Um aspecto importante a ser destacado é o fato de a política urbana e habitacional de SBC ter incorporado o PRIS como um importante instrumento urbanístico e de caráter simultaneamente ambiental a ser utilizado nas ARA 1, conforme determina a lei específica. As ARA 1 foram grafadas no território da sub-bacia e coincidem com a proposição de ZEIS - Zonas Especiais de Interesse Social, definidas pelo PDSBC.

Segundo estudo da PMSBC (2012), o mapeamento dos loteamentos precários e/ou irregulares foi instrumento fundamental para a revisão da delimitação das ZEIS, ${ }^{7}$ no Plano Diretor em articulação com as demarcações de ARA e a definição PRIS e outros instrumentos que garantam a regularização fundiária e o direito à moradia. 0 estudo concluiu que a distribuição da demanda por habitação de interesse social em SBC se dá $65 \%$ fora dos mananciais e $35 \%$ dentro dos mananciais. $\mathrm{Da}$ necessidade de terra grafada como ZEIS em APRM-B para implantação de novos programas habitacionais, $85 \%$ se encontra entre o divisor das sub-bacias do rio Tamanduateí e do reservatório Billings e do sistema viário Rodoanel, ao norte. Nesse nível, a definição de instrumentos de ação buscam enquadrar as preexistências urbanas e as fortes demandas habitacionais a objetivos ambientais de recuperação das áreas afetadas.

Num balizamento mais amplo, apesar do novo Plano Diretor de São Bernardo do Campo de 2011 ter como propósito a adequação de seus parâmetros e instrumentos à lei estadual que define a área de proteção e recuperação dos mananciais do reservatório Billings, o estudo de compatibilização realizado pela prefeitura indicou diversos conflitos entre a lei estadual e a realidade de ocupação do território, recomendando inclusive ajustes de suas subáreas. 0 estudo, encaminhado para a Secretaria Estadual do Meio Ambiente (SMA) no final de 2012, não foi aceito, conforme entrevista realizada com técnicos da Secretaria de Planejamento Urbano e Ação Regional 
de São Bernardo do Campo, realizada em março de 2014. Durante os anos de 2013 e 2014, o debate entre Estado e Município prosseguiu, culminando na adequação dos instrumentos municipais (Plano Diretor, Lei de Parcelamento, Uso e Ocupação do Solo e Zonas Especiais de Interesse Social) às diretrizes e parâmetros da Lei específica da APRM-B.

Paralelamente, a Secretaria Municipal de Habitação, atendendo as diretrizes do Plano Local de Habitação de Interesse Social (PMSBC, 2012b), vem implementando um conjunto de intervenções, nas quais se destacam os projetos de recuperação de interesse social. Nesses projetos as ações propositivas elencadas se dão em diferentes escalas de planejamento e gestão, em que o projeto urbanístico assume caráter diferenciado.

\section{Projetos habitacionais em áreas de PRIS em São Bernardo do Campo}

A Lei Específica da Billings n.13.579/2009, ao possibilitar processos de intervenção urbanística em assentamentos precários por meio das novas premissas e estratégias que norteiam e justificam sua edição, apresenta, dentre os novos instrumentos disponibilizados, o Programa de Recuperação de Interesse Social - PRIS, configurando possibilidades inovadoras de atuação, por meio de novos arranjos políticos e institucionais.

Os PRIS grafados em ARA 1 devem indicar parâmetros que permitem ao Poder Público municipal atuar em áreas degradadas a fim de recuperá-las. A lei específica da Billings define que a elaboração e a implantação do PRIS, além de ser responsabilidade do Poder Público, deve ser compartilhada "com as comunidades residentes no local, organizadas em associação de moradores ou outras associações civis, bem como com o responsável pelo parcelamento e/ou proprietário da área" (Art. 33). Para a obtenção do licenciamento do PRIS, o organismo competente deve apresentar um Plano de Urbanização (Art. 79) que contenha projeto de parcelamento do solo, para fins de urbanização específica, em seu perímetro. Ou seja, a exigência de um plano pressupõe o detalhamento de um projeto que garanta a qualidade urbano-ambiental da área. De modo geral, são previstos ações de regularização dos parcelamentos do solo, empreendimentos, edificações e atividades, desde que comprovadas as preexistências até 2009. Particularmente em relação à regularização dos assentamentos habitacionais em ARA 1, a lei da Billings dedica uma seção inteira para tratar do assunto. A Seção III (arts. 77 e 83), que trata "Da Regularização de Assentamentos Habitacionais de Interesse Social - ARA 1", dispõe que os "assentamentos habitacionais de interesse social enquadrados como ARA 1", implantados até 2006, serão objeto de PRIS e são passíveis de regularização. 0 processo de regularização fundiária pode ter início concomitante à execução das obras e ações urbanísticas ambientais; seu término "está condicionado à comprovação de que as condições de saneamento ambiental estabelecidas pelo PRIS sejam efetivamente mantidas durante um prazo mínimo de dois anos, contados a partir do término das intervenções, com a participação da população local beneficiada" (Art. 82). Enfim, embora o Poder público municipal seja o responsável pela proposição, 
elaboração, implementação e gestão do PRIS, o licenciamento e a regularização fundiária são concedidos pelo órgão responsável no sistema de gestão; no caso, o Estado, por meio da SMA e Cetesb.

Em conformidade com discussões anteriormente realizadas, a Lei Específica da Billings traz componentes significativos para responder às externalidades intrínsecas ao processo de planejamento voltado aos propósitos da recuperação da área ocupada inadequadamente e à definição de mecanismos e estratégias aptas em frear a ocupação de novas áreas, considerando a importância da qualificação dos assentamentos precários por meio da implantação de infraestrutura física, social e ambiental, para além de criar uma cultura diferenciada, ao compreender a necessidade de elaboração de projetos urbanos pautados por concepções inovadoras, fundamentados em tecnologias avançadas e orientados pelos princípios do urbanismo sustentável.

Essa visão permite uma abordagem em que a diversidade de proposições urbanísticas encontra um campo fecundo, de modo a possibilitar que suas ações sejam caracterizadas pela capacidade de articulação e incorporação das diferentes dimensões e temporalidades específicas de cada produto do processo de planejamento, como o plano de saneamento ambiental, de habitação, de desenvolvimento territorial, dentre outros essenciais ao processo de construção da sustentabilidade. Para Muñoz (2000), a condição da sustentabilidade é própria ao conceito de desenvolvimento e só é passível de se tornar realidade quando associada à equidade social decorrente de um processo distributivo de uma economia ativa, porém implementada em observância com a capacidade de suporte dos ecossistemas. Dessa forma, faz-se necessário que a concepção de um processo de planejamento e gestão, ao incorporar mecanismos adequados à nova realidade urbana, possibilite aos agentes políticos e sociais a escolha de alternativas-soluções que tenham como objetivo principal alcançar o desenvolvimento econômico, a equidade e a sustentabilidade ambiental da bacia hidrográfica.

Apesar de previstos pelas legislações específicas, os Programas de Recuperação de Interesse Social (PRIS) se esbarravam com a falta de procedimentos claros por parte do órgão técnico, a Secretaria Estadual de Meio Ambiente. Essa lacuna foi resolvida posteriormente, com a instituição da Resolução SMA n. 25 de abril de 2013 que estabelece critérios específicos de licenciamento ambiental dos PRIS no âmbito das bacias hidrográficas dos Reservatórios Billings e Guarapiranga. 0 processo de implementação de um PRIS dependerá de um conjunto de procedimentos que se encontram no âmbito da emissão das Licenças Prévia, de Instalação e de Operação, todas de responsabilidade do agente promotor (na maioria das vezes a municipalidade) e que devem ser analisadas pela Cetesb, órgão técnico responsável pelo licenciamento do empreendimento. Apesar dessa medida estabelecer os procedimentos para a viabilização dos PRIS, a exigência de averbação dos títulos de propriedade dos imóveis por ele abrangidos, quando implementados em áreas privadas, vem sendo alvo de críticas pelos agentes promotores. Destaca-se que a dominialidade das propriedades é uma dificuldade no âmbito do cadastro municipal, visto que a maioria das áreas degradadas encontra-se em loteamentos irregulares ou é área invadida, cuja titularidade 
é incerta e demandaria procedimentos urbanísticos de regularização fundiária, no geral complexos e de longo prazo. Essa dificuldade indica o quão longe está a possiblidade de uma articulação profícua entre as agendas ambientais e urbanas.

A prefeitura de São Bernardo do Campo vem buscando implementar uma articulação entre instrumentos ambientais e urbanos, ou seja, um conjunto de PRIS a partir das delimitações de ZEIS em áreas de mananciais. 0 enfoque das experiências em PRIS em São Bernardo do Campo pauta-se em referenciais conceituais que visam enfrentar o desafio de articular as legislações ambiental e urbana, bem como a realidade, reafirmando o papel da intersetorialidade das políticas públicas.

O Plano Habitacional de Interesse Social - PHLIS (São Bernardo, 2011) aponta um número significativo de assentamentos precários em área de proteção dos mananciais nesse município: 83 loteamentos irregulares, 68 núcleos de favelas, com uma taxa de remoção que alcança $40 \%$ do total de famílias, conformando um quadro de futuros desafios para a administração local.

Figura 3 - Tipologias de PRIS em São Bernardo do Campo

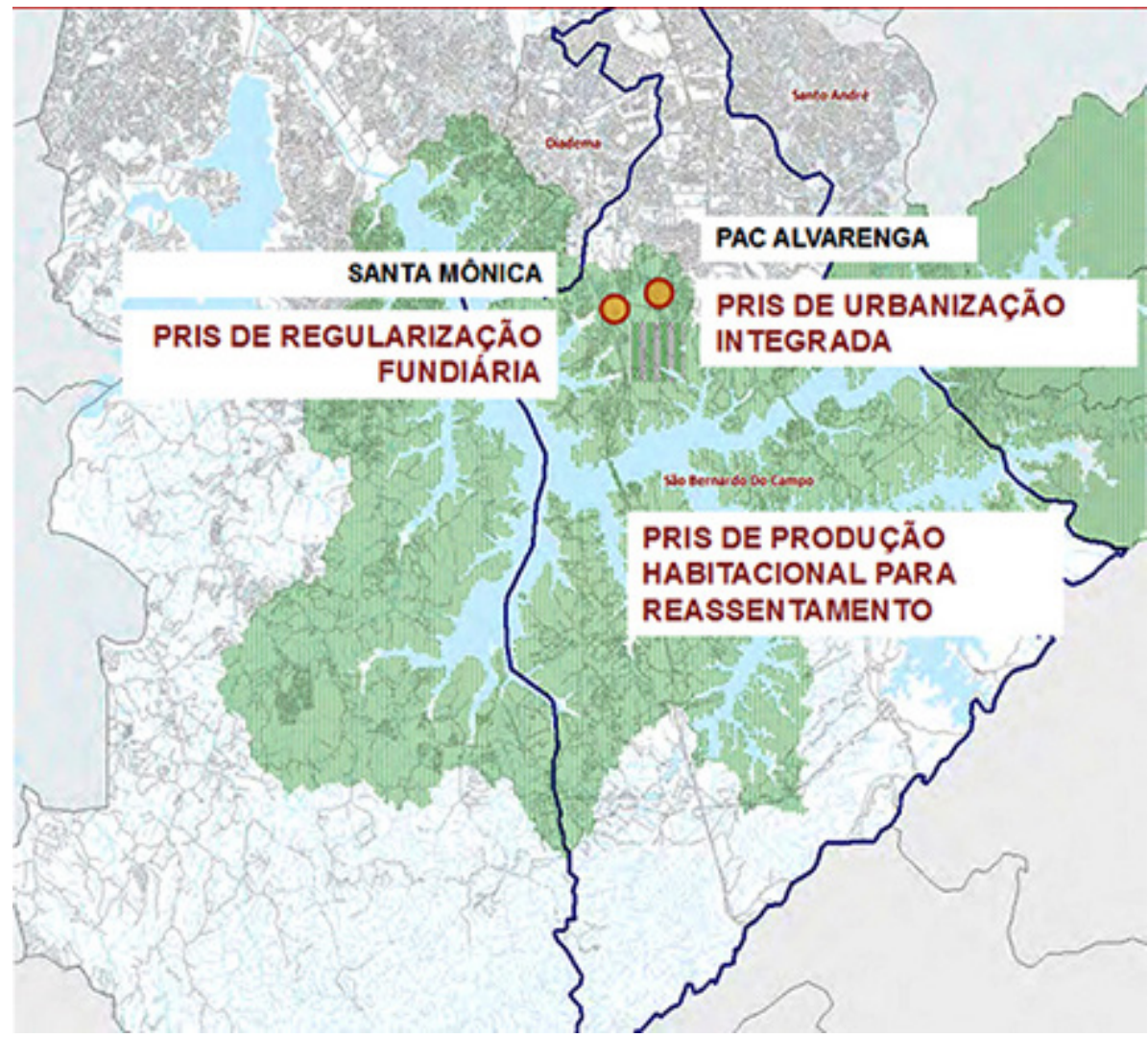

Fonte: Regino, Tassia, Apresentação no Banco Mundial. Disponível em: http://siteresources.worldbank.org/INTLAC/ Resources/257803-1351801841279/ApresTassia_Seminario_.pdf. Acesso em: 11 abril 2014. 
As experiências em curso permitem observar de que maneira a legislação específica e as normas ambientais recentes são materializadas em projetos de urbanização, e ainda, de que forma os sistemas de infraestrutura de saneamento ambiental são contemplados e integrados no processo de urbanização desses núcleos. A Figura 3 localiza os tipos de PRIS em andamento em São Bernardo do Campo.

Os Programas de Recuperação de Interesse Social - PRIS em São Bernardo do Campo, além de definir instrumentos voltados à proteção e recuperação de áreas de preservação permanente (APP), com intuito de garantir a produção de água em patamares qualitativos e quantitativos aos mais diversos usos, atuam sobre as preexistências urbanas. Os projetos atualmente em curso envolvem diversas ações que demandam continuidade e esforços significativos que contribuam para sua efetividade. Uma ação fundamental refere-se ao sistema de esgotamento sanitário; sabe-se que a exportação de efluentes para fora da bacia, visando a recuperação de suas águas, é uma condição estratégica que deve ser melhor conduzida, inclusive com o tratamento de esgotos em sua totalidade.

A implementação dos PRIS em áreas de mananciais tem natureza multiescalar envolvendo diversas dimensões - sociais, ambientais e econômicas - e, necessariamente, enfrenta diversos desafios em que se confrontam as preexistências e a necessidade de remoção da população localizada em áreas de risco. 0 enfrentamento dos problemas urbanos e ambientais em áreas de mananciais tenta implementar soluções inovadoras com vistas à proteção e recuperação de mananciais nessa sub-bacia.

\section{Considerações finais}

0 processo intenso e desordenado de ocupação do território metropolitano ocorrido ao longo das últimas décadas impactou decisivamente as áreas produtoras de água. Se, por um lado, a escassez da água é severa na atualidade, colocando em risco a sustentabilidade do próprio desenvolvimento socioeconômico, por outro, a escassez e o preço do solo em áreas propícias à urbanização, aliados à ausência de políticas públicas, particularmente habitacionais e de infraestrutura voltadas para a população mais pobre, acabaram por induzir a ocupação irregular em áreas protegidas, contribuindo para acirrar os conflitos entre a preservação ambiental e o direito à moradia.

No contexto recente, no âmbito das áreas de proteção dos mananciais da RMSP, a instituição de novos instrumentos urbanos e ambientais vem introduzindo um processo de planejamento e gestão das bacias hidrográficas que tem como princípio fundamental a integração sistêmica e o envolvimento de um processo negociado e compartilhado entre os principais atores e instituições. Trata-se da implementação de um novo olhar sobre as bacias hidrográficas, o qual busca aliar ações de preservação e de recuperação ambiental e urbana num processo de diálogo permanente com os principais atores e instituições regionais e locais. Tal situação envolve duas questões aparentemente contraditórias: o habitar e o preservar. Embora essas áreas devam ser analisadas sob o aspecto da importância da água como recurso natural e finito, não podemos descartar a presença humana que habita esses territórios. 
As legislações recentes em Áreas de Proteção dos Mananciais pressupõem adequações e convergências entre instâncias de governo e entre políticas setoriais definindo instrumentos mais avançados e adequados à magnitude dos problemas urbanos e ambientais da metrópole. Os processos participativos aí inseridos, tanto na instância do Comitê de Bacia quanto na reformulação dos planos diretores municipais, se contrapõem ao perfil histórico setorial das políticas e, por isso mesmo, demandam experiências e aprendizados, ajustes e correções.

As análises realizadas permitem identificar um avanço importante no processo de formulação da política urbana de São Bernardo do Campo. Ao mesmo tempo em que o Plano Diretor incorpora diretrizes e parâmetros de regulação e instrumentos de intervenção propostos pela lei específica da APRM-B, esse indica a necessidade de revisão dos procedimentos de aplicação do instrumento ambiental com vistas à recuperação da realidade de ocupação do território.

No âmbito desse processo, convergências e conflitos entre Estado e município são deflagrados, indicando que a compatibilização entre os instrumentos urbanos e ambientais é necessária, porém insuficiente. $A$ formulação de políticas convergentes representa um avanço histórico necessário e importante em relação às questões urbanas e ambientais; entretanto, no âmbito das práticas, interesses divergentes afloram e constituem uma arena de conflitos e tensões. Daí a importância do olhar para as especificidades dessas manifestações.

Apesar de a política ambiental em curso indicar possibilidades de incorporação dos instrumentos urbanísticos e vice-versa, os desafios para a recuperação das áreas de mananciais vão além da instituição dos marcos legais. Dependem fundamentalmente de um processo de negociação entre os organismos estaduais e municipais, em um diálogo permanente com prioridades e adequação de projetos e, sobretudo, incorporando estratégias de intervenção inovadoras que envolvam a sociedade civil e que possam sinalizar uma transformação da realidade das bacias hidrográficas protegidas.

Diante dos novos marcos legais configurados com a Lei Específica da Billings, evidencia-se em São Bernardo do Campo a premência de intervir nos territórios situados nas áreas de proteção e recuperação dos mananciais - APRMs com a definição de critérios específicos voltados para a recuperação dos recursos hídricos. Ao incorporar a realidade de ocupação da bacia hidrográfica, São Bernardo do Campo define um conjunto de Programas de Recuperação de Interesse Social - PRIS com o objetivo de garantir a manutenção da moradia e a recuperação socioambiental das áreas protegidas. Tendo em vista a abrangência e complexidade que envolve cada projeto, os efeitos para a melhoria da qualidade urbano e ambiental dependerão da capacidade de gestão e do nível de articulação entre os diversos atores que atuam no âmbito das intervenções realizadas.

Ainda que a pesquisa tenha se debruçado sobre os resultados dos esforços de integração das políticas ambientais e urbanas no âmbito da institucionalização de instrumentos regulatórios e de intervenção, envolvendo o território das áreas de mananciais Billings e Guarapiranga e, sobretudo, as investigações empíricas no município de São Bernardo do Campo, esses aspectos não podem ser vistos 
descolados das dinâmicas políticas de aproximação e diálogo entre atores, que lhes dão origem e que podem alterar seus rumos. Vale dizer que nesse horizonte de integração de políticas publicas, coloca-se em jogo os processos reais, também como objeto de investigação.

É fato que a implementação dessas legislações representa hoje um avanço inegável para a realidade das áreas de mananciais, pois não só incorporam a dimensão urbana nas políticas ambientais, mas também estabelecem referenciais para a redefinição das políticas locais e setoriais. No entanto, a comple- xidade do conteúdo das Leis Específicas, que dificultam sua aplicabilidade, e o antagonismo entre a legislação ambiental, a legislação municipal de uso e ocupação do solo, e a realidade das bacias, são ainda parte de um cenário em construção.

Enfim, o grande desafio para as áreas de mananciais é a implementação de um conjunto de políticas ambientais e urbanas articuladas a um modelo de ocupação urbana que priorize ações socioambientais e que reconheçam a urgência das águas para todos os habitantes da metrópole.

\section{Angélica Tanus Benatti Alvim}

Universidade Presbiteriana Mackenzie, Faculdade de Arquitetura e Urbanismo, Programa de Pós-Graduação em Arquitetura e Urbanismo. São Paulo/SP, Brasil.

angelica.alvim@mackenzie.br

\section{Volia Regina Costa Kato}

Universidade Presbiteriana Mackenzie, Faculdade de Arquitetura e Urbanismo. São Paulo/SP, Brasil. vrkato@uol.com.br

\section{Jeane Rombi de Godoy Rosin}

Universidade Presbiteriana Mackenzie, Faculdade de Arquitetura e Urbanismo, Programa de Pós-Graduação em Arquitetura e Urbanismo. São Paulo/SP, Brasil. jeanerosin@terra.com.br 


\section{Notas}

(1) Este artigo é fruto de reflexões advindas de um conjunto de pesquisas desenvolvidas desde 2008 por pesquisadores do Programa de Pós-Graduação em Arquitetura e Urbanismo e do curso de Graduação da Faculdade de Arquitetura e Urbanismo da Universidade Presbiteriana Mackenzie, sob liderança da profa. Angélica T. Benatti Alvim. Merecem destaque os resultados recentes da pesquisa "Das Políticas Ambientais e Urbanas às Intervenções: Conflitos, Desafios e Possibilidades para Áreas Protegidas", que teve auxílio financeiro do Fundo Mackpesquisa entre 2012 e 2013, e os avanços da pesquisa em andamento “Políticas Públicas e Projetos Urbanos na Cidade Contemporânea: Limites e Perspectivas para a recuperação de assentamentos precários localizados em áreas protegidas no meio urbano", desenvolvida pela líder do projeto no âmbito de sua Bolsa Produtividade do CNPq.2014, nível 2.

(2) A Lei de Proteção dos Mananciais de 1976 contribuiu para o grande descompasso entre os processos de ocupação do território que se dão por meio de invasão, autoconstrução e de outros mecanismos de urbanização precária. A concepção de congelamento legal do território voltado para a preservação ambiental não foi capaz de conter a força dos processos reais de ocupação.

(3) Segundo a ONU, a disponibilidade hídrica abaixo de 1,5 mil metros cúbicos por habitante por ano já é considerada crítica.

(4) A Bacia do Alto Tietê, a montante da barragem de Pirapora, abrange uma área de drenagem de $5.720 \mathrm{~km}^{2}$, e tem as seguintes unidades geográficas, as sub-bacias: Cabeceiras, Cotia-Guarapiranga, Penha-Pinheiros, Pinheiros-Pirapora, Juqueri-Cantareira e Billings. Em função da importância da bacia do Alto Tietê, dentro do Estado de São Paulo, sua conexão com bacias vizinhas como a do Piracicaba e da Baixada Santista, e a importância desse Estado dentro do país, já se pode antecipar o impacto que podem ter no ponto de vista social, econômico e ambiental, as ações que serão adotadas dentro desta bacia que, em última análise, visam permitir o uso de seus recursos hídricos de maneira sustentável. A Unidade de Gerenciamento de Recursos Hídricos - UGRHI 06 está dividida em cinco subcomitês: Tietê-Cabeceiras, Billings-Tamanduateí, Juqueri-Cantareira, Cotia-Guarapiranga e Pinheiros-Pirapora.

(5) São Bernardo do Campo encontra-se na sub-bacia Billings ao lado de outros cinco municípios: São Paulo, Diadema, Santo André, Ribeirão Pires e Rio Grande da Serra. Essa ocupa um território de $583 \mathrm{~km}^{2}$, sendo $108 \mathrm{~km}^{2}$ em espelho d'água, correspondendo a cerca de $18 \%$ de sua PRIME, SMA (2005). Segundo dados do Censo Demográfico de 2000, a população residente, nessa sub-bacia, na ocasião era de 865.870 habitantes, dos quais aproximadamente $20 \%$ viviam em aglomerados subnormais (PRIME/SMA, ibid.).

(6) Para maior aprofundamento ver ALVIM, Angélica T. Benatti; KATO, V. R. C. ; BRUNA, G. C. Políticas Urbanas e Ambientais em áreas protegidas: percursos para uma integração possível. In: TAMARA T. COHEN EGLER; HERMES M. TAVARES. (Org.). Política pública, rede social e território. 1ed. Rio de Janeiro: Letra Capital, 2012, v. UNICO, pp. 103-128.

(7) Foram definidos dois tipos de ZEIS: a) ZEIS I - áreas ocupadas predominantemente por população de baixa renda, abrangendo favelas, loteamentos irregulares e empreendimentos habitacionais de interesse social, em que haja interesse público em promover recuperação urbanístico-ambiental, regularização fundiária ou produção de Habitação de Interesse Social - HIS; b) ZEIS 2 - constituídas por áreas não edificadas ou subutilizadas, destinadas à produção de Habitação de Interesse Social (HIS) e Habitação de Mercado Popular (HMP). 


\section{Referências}

ALVIM, A. T. B (2003). Contribuição do Comitê do Alto Tietê à Gestão da Bacia Metropolitana, 19942001. Tese de Doutorado. São Paulo, Universidade de São Paulo.

(2010). “Assentamentos irregulares e proteção ambiental: impasses e desafios da nova legislação estadual de proteção e recuperação dos mananciais na Região Metropolitana de São Paulo". In: BOGUS, L. M. M. et al. (orgs.). Reconversão e reinserção urbana de loteamento de gênese ilegal: análise comparativa Brasil-Portugal. São Paulo, Educ.

ALVIM, A. T. B et al. (2014). Das políticas públicas ambientais e urbanas às intervenções: os casos das Sub-Bacias Guarapiranga e Billings no Alto Tietê. Relatório de pesquisa. São Paulo, Faculdade de Arquitetura e Urbanismo, Universidade de São Paulo/Fundo Mackpesquisa.

ALVIM, A. T. B.; BRUNA, G. C. e KATO, V. R. C. (2008). Políticas ambientais e urbanas em áreas de mananciais: interfaces e conflitos. Cadernos Metrópole. São Paulo, v. 19, pp. 143-164.

ALVIM, A. T. B.; KATO, V. R. C. e BRUNA, G. C. (2012). "Políticas urbanas e ambientais em áreas protegidas: percursos para uma integração possível”. In: EGLER, T. T. C. e TAVARES, H. M. (orgs.). Política pública, rede social e território. Rio de Janeiro, Letra Capital.

ANCONA, A. L. (2002). Direito ambiental, direito de quem? Políticas públicas do meio ambiente na Metrópole Paulista. Tese de Doutorado. São Paulo, Universidade de São Paulo.

BRASIL (1997). Lei Federal N. 9.433, de 8 de janeiro de 1997. Institui a Política Nacional de Recursos Hídricos, cria o Sistema Nacional de Gerenciamento de Recursos Hídricos, regulamenta o inciso XIX do art. 21 da Constituição Federal, e altera o art. 1o da Lei no 8.001, de 13 de março de 1990, que modificou a Lei n. 7.990, de 28 de dezembro de 1989. Disponível em: http://www.planalto. gov.br/ccivil_03/leis/19433.htm. Acesso em: 15 ago 2002.

DOUROJEANNY, A. (1993). Las cuencas hidrográficas: uma opición territorial para dirigir acciones tiendes la sustentabilidad ambiental. In: TERCERA CONVENCIÓN NACIONAL DE REGENTES Y USUÁRIOS DEL ÁGUA. Los Angeles, Chile, Conferencia de Canalistas Del Chile.

EGLER, T. T. C. e TAVARES, H. M. (orgs.). (2012). Política pública, rede social e território. Rio de Janeiro, Letra Capital.

FRACALANZA, A. P. (2002). Conflitos na apropriação da água na Região Metropolitana de São Paulo. Tese de Doutorado. Universidade Estadual Paulista, Presidente Prudente.

MARTINS, M. L. R. (2006). Moradia e mananciais. Tensão e diálogo na metrópole. São Paulo, FAUUSP/ Fapesp.

MENDONÇA, F. A. e LEITÃO, S. A. M. (2008). Riscos e vulnerabilidade socioambiental urbana: uma perspectiva a partir dos recursos hídricos. GeoTextos, v. 4, n. 1 e 2, pp. 145-163.

MUNÕZ, H. (org.) (2000). Interfaces da gestão de recursos hídricos - desafios da lei de águas em 1997. Brasília, Ministério do Meio Ambiente, Secretaria de Recursos Hídricos. Disponível em: http// www.mma.gov.br. Acesso em: 7 abr 2002. 
OLIVEIRA, M. A. de e ALVES, H. P. da F. (2006). Crescimento populacional e mudanças no uso e cobertura do solo nas áreas de proteção aos mananciais da Região Metropolitana de São Paulo: uma análise a partir da aplicação de metodologias de sensoriamento remoto e geoprocessamento. In: III ANPPAS - ENCONTRO NACIONAL DE PÓS- GRADUAÇÃO E PESQUISA EM AMBIENTE E SOCIEDADE. Brasília. Anais. Campinas, Associação Nacional de Pesquisa em Pós-Graduação em Ambiente e Sociedade, v. único, pp. 1-20.

SÃO BERNARDO DO CAMPO (MUNICÍPIO). (2006). Lei n. 5593, de 5 de outubro de 2006. Aprova o Plano Diretor do Município de São Bernardo do Campo, e dá outras providências. In: Leis Municipais. Disponível em: https://www.leismunicipais.com.br/a/sp/s/sao-bernardo-do-campo/ lei-ordinaria/2006/559/5593/lei-ordinaria-n-5593-2006-aprova-o-plano-diretor-do-municipiode-sao-bernardo-do-campo-e-da-outras-providencias.html. Acesso em: 14 out 2009.

(2010). Secretaria de Habitação. Sumário de Dados 2010 (ano base 2009). São Bernardo do Campo, PMSBC.

(2011). Lei № 6184, de 21 de dezembro de 2011. Dispõe sobre a aprovação do Plano Diretor do município de São Bernardo do Campo e dá outras providências. In Leis Municipais. Disponível em: https://www.leismunicipais.com.br/plano-diretor-sao-bernardo-do-campo-sp. Acesso em: 10 ago 2012.

(2012a). Compatibilização do Plano Diretor do município de São Bernardo do Campo à Lei Estadual n. 13.579, de 13 de julho de 2009. São Bernardo do Campo, Relatório Técnico.

(2012b). Plano Local de Habitação de Interesse Social 2010-2025. Produto Final consolidado. São Bernardo do Campo.

SÃO PAULO (ESTADO) (1991). Lei Estadual n. 7.663, de 30 de dezembro de 1991. Institui a Política Estadual de Recursos Hídricos. In: SÃO PAULO. SECRETARIA ESTADUAL DE RECURSOS HÍDRICOS, SANEAMENTO E OBRAS. (2002). Legis/ação. Disponível em: <http://www.daee.sp.gov.br/images/ documentos/legislacaoeafins/LEI_76631991.pdf>. Acesso em: 10 ago 2011.

(1997). Lei Estadual n. 9.866, de 28 de novembro de 1997. Dispõe sobre diretrizes e normas para a proteção e recuperação das bacias hidrográficas dos mananciais de interesse regional do Estado de São Paulo. In: Legislação de Recursos Hídricos. Disponível em: http://www.daee. sp.gov.br/images/documentos/legislacaoeafins/lei_9866.pdf. Acesso em: 10 ago de 2011.

(2006). Lei Estadual n. 12.233 de 17 de janeiro de 2006. Define a Área de Proteção e Recuperação dos Mananciais da Bacia Hidrográfica do Guarapiranga, e dá outras providências correlatas. Disponível em: http://homologa.ambiente.sp.gov.br/EA/adm/admarqs/LeiEst_12233.pdf. Acesso em: 10 ago 2011.

(2009). Lei Estadual n. 13.579, de dezembro de 2009. Define a Área de Proteção e Recuperação dos Mananciais da Bacia Hidrográfica da Billings e dá outras providências correlatas. Disponível em: http://www.jusbrasil.com.br/legislacao/818001/lei-13579-09-sao-paulo-sp. Acesso em: 10 ago 2011.

(2013). Secretaria de Estado do Meio Ambiente. Licenciamento ambiental dos Programas de Recuperação de Interesse Social - PRIS, no âmbito da Legislação Estadual de Proteção e Recuperação dos Mananciais das Bacias Hidrográficas dos Reservatórios Billings e Guarapiranga. Resolução no 25 . São Paulo. Disponível em: http://www.ambiente.sp.gov.br/legislacao/ files/2013/04/Resolução-SMA-025-2013-Processo-931-2013-Programa-de-Recuperação-deInteresse-Social-PRIS.pdf. Acesso em: 3 ago 2012. 
SARAIVA, M. G. (1999). O Rio como Paisagem. Lisboa, Fundação Calouste Gulbenkian/Fundação para a Ciência e Tecnologia.

TOLEDO SILVA, R. (2002). "Gestão Integrada de Bacias Hidrográficas densamente urbanizadas". In: FONSECA, R. B. (org.). Livro Verde: desafios para a gestão da Região Metropolitana de Campinas. Campinas, Unicamp.

(2014). Águas e saneamento da metrópole: a atualidade dos desafios passados. Revista DAE, v. 62, n. 196. Edição Especial. Disponível em: http://revistadae.com.br/downloads/Revista_DAE_ Edicao_196.pdf. Acesso em: 10 nov 2014.

Texto recebido em 13/set/2014

Texto aprovado em 3/dez/2014 
